\title{
History, power, communication, journalism: Beyond the "traditional" critical approach
}

\author{
Ramón Reig
}

Nota: Este artículo se puede leer en español en:

http://www.elprofesionaldelainformacion.com/contenidos/2019/nov/reig_es.pdf

How to quote this article:

"Reig, Ramón (2019). "History, power, communication, journalism: Beyond the 'traditional' critical approach".

El profesional de la información, v. 28, n. 6, e280502.

https://doi.org/10.3145/epi.2019.nov.02

Manuscript received on September, $07^{\text {th }} 2019$ Accepted on September, $22^{\text {nd }} 2019$

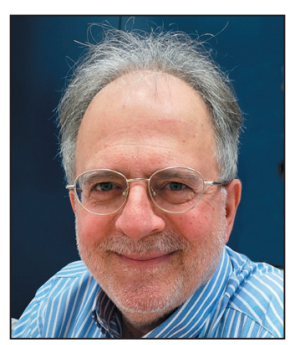

\author{
Ramón Reig $\square$ \\ http://orcid.org/0000-0003-2663-4223 \\ Universidad de Sevilla \\ Facultad de Comunicación \\ Departamento de Periodismo II \\ Américo Vespucio, s/n, Isla de La Cartuja \\ 41092 Seville, Spain \\ ramonreig@us.es
}

\begin{abstract}
This article is not going to limit itself to presenting the traditional dualist view of good versus bad (the good is represented by average citizens manipulated by the bad, which is the capitalist media-driven society). Such views have their origin point in the Marxist or neo-Marxist school of thought, which was strictly adhered to by the (first generation) of the Frankfurt School, and it is known as critical thinking. This research supports the fundamentals of critical thinking, but additionally argues that "critical thinking" exists also to criticize itself, to overcome it, and to enter into what we call "Complex Structural Approach" (CSA). The Power is, to a large extent, the market in evolution and involution and acts today through the marginalization of universal historical memory and philosophy, among other knowledge, and is replaced by infoxication. The western citizen is not completely unaware of its dependency. The virtual-intelligent society of the $21^{\text {th }}$ century connects with one of the innate characteristics of the individual: his selfishness, whether it is positive or destructive behavior, in various formats and in varying degrees.
\end{abstract}

\section{Keywords}

Power; Communication; Journalism; XXI century; History; Complexity; Structural approach; Structural theory; Media; Press; Business; Multinationals; Globalization; Political economy of information; Critical analysis; Critical thinking; Critical theory; Democracy; Artificial intelligence; Society; Control.

\section{Introduction}

Interrelationships between power and communication may be the cinderella line of research in communication and journalism studies worldwide. There is evidence this has been going on for some time, at least in Spain (Almiron; Reig, 2007). In the JCR journals we find it crouched in other texts, but rarely "with the open face". If we refer to systematized studies on the subject -better than limited articles on matters in this field that tend to appear somewhat outdated in the so-called source journals- we have the well-known works by Quirós (1998), Curran (2005), Castells (2009), Serrano (2009), Becerra and Mastrini (2009), Campos-Freire (2012) or Reig $(2010 ; 2011)$, among others, such as works in the United States and the rest of the world by Herman and McChesney (2001; 2013), Labio (2006,) or Segovia-Alonso (2001), the latter focused more in recent years on communication policies, communication and culture, and digital writing.

The interrelationships between power and communication may be the cindereIla research line of communication and journalism studies worldwide 
We owe the most recent references in Spanish and English literature to Martínez-Vallvey and Núñez-Fernández (2016); García-Santamaría (2016); Reporteros Sin Fronteras (RSF) -Reporters Without Borders (RWB)- (2016); Mancinas-Chávez (2016); Serrano (2016); Birkinbine, Gómez and Wasco (2017); Reig and Labio (2017); Puentes-Rivera, Campos-Freire, and López-García (2018). The latter authors place journalism on the structural stage starred by the new technologies applied to the profession. López-García has completed his work with another publication: Toural-Bran and López-García (2019). We believe that the study of media structures should focus intensely on the digital native world and this work offers us a foundation for it. For its part, from the Anglosphere comes a new edition of the book by Hesmondhalgh (2019), the last part of which is especially useful for our field of work.

We also receive news -or rather reoccurrences- about theories, and analysis of the supposed perverse effects of globalization, as well as a multitude of works on digital technologies and analysis of information or media treatment of certain groups, but the odd thing is that, according to what we have observed, much less work has been done relating to the Structural Approach (SA) and the Political Economy of Information, Communication, and Culture (PEICC) (CIC, 2006), which comprise the underpinnings of communication studies and power. PEICC is about researching what underlies the communication phenomenon, that is, what underlies the events, according to the structural theory (Muñoz, 2005).

It is well known that the media influence the social way of thinking and that the most influential are in the hands of non-specific entrepreneurs in the communication and journalistic sector. But it is not enough to affirm this again and again: it must be proven in order to explain why a message is constructed in one way or another.
The media influence the social way of thinking and the most influential are in the hands of non-specific entrepreneurs in the communication and journalistic sector

The first conclusion is not difficult to draw: research in communication and journalism usually swims on the surface, at most a few meters below; research does not usually investigate the foundations of the iceberg nor the base on which the power of the network is founded. It is this power that determines the work of journalists and, subsequently, the behavior of humankind in general. In our research, we are not going to limit ourselves to presenting the typical dualistic vision good/bad extracted from the simplistic Marxist or neo-Marxist approaches, inherited in turn by the first generation of the Frankfurt School, in what we know as critical thinking. This work is part of critical thinking, but estimates that critical thinking also exists to criticize critical thinking itself, overcome it, and get into what we now call Complex Structural Approach (CSA) (Reig; Mancinas-Chávez; Nogales-Bocio, 2017).

\section{Theoretical-methodological foundations}

We have no doubt that the Structural Approach (SA) and the PEICC assume that throughout History human beings have created power structures and, within them, communicational power structures that have been necessary to project messages -strategies of information in our times- in order to try to preserve power through mental modeling, even in the current prosumer time. In this sense, the PEICC and the CDA (Critical discourse analysis) go hand in hand. But we must go further, and although this is not an adequate article to delve into the subject, we will take a look at it, because for many years the critical approach has been causing us considerable weariness by continuously harping on the same discourse and not going beyond a mental-movie where corporations are entities that destroy everything and citizens are poor victims. It's time to move beyond this dualistic rhetoric.

Above all, what sustains this article is a branch with its own personality derived from the stem-matrix Structural approach (SA). We call that branch Simple structural approach (SSA), intimately related to the historical perspective, which is based on these words (Cardoso; Pérez-Brignoli, 1976) referring to the historical dynamics of conjuncture-structure:

"By conjuncture we understand first of all movement: increases and decreases in production, fluctuations in the volume of exchanges, price variations ... [...]. Let us now observe an important fact: the conjuncture, the movement of economic life, is characterized by repetition, recurrence. Upward movements are followed by downward movements, then return to the upward, etc. This usually means that economic fluctuations are considered cyclical, and more commonly spoken of economic cycles. Thus, "conjuncture, as a repeated phenomenon, is therefore a structural phenomenon" [Ernest Labrousse]. In this way, the movement does not appear as anarchic or random, but rather presenting in the background a series of regularities, of repetitions that make possible to study it. Now, we can say with legitimacy that the movement is cyclical, by comparison to something stable: it is this permanence that we call structure. We define the structure as "a set of majority relations" (in other words, a "constellation of solidary dominants"), the solidarity and proportion existing among a set of components, the interdependence between the whole and the parts". 
From the SSA branch another one emerges, the Political Economy (PE) and, in turn, in our field the PE is completed with the Political Economy of Communication (PEC). Mosco (2006) addresses the meanings of PE and PEC. For this author, in a strict sense, political economy is the study of social relations, particularly power relations, which mutually constitute the production, distribution, and consumption of resources, including communication resources. The PE consequently places, in the foreground, the objective of understanding social change and historical transformation, which involves the empirical investigation of the market's behavior beyond a functional vision to result in its effects on society and the individuals. The PEC - of undoubted Marxist origin, says Mosco-

"has stood out for its emphasis on describing and examining the meaning of institutions, especially companies and governments, responsible for the production, distribution, and exchanges of communication goods and for the regulation of the communication market."

For our part, in other works (Reig, 2010) we have established that it is more correct to talk about PEICC (Political economy of information, communication, and culture) in order to link it with the Critical Discourse Analysis (CDA), which links the communication message to the property and systemic interests attached to the media, especially to the most ubiquitous in the commercial space. The CDA is focused
It is more correct to talk about PEICC (Political economy of information, com- munication, and culture) to link in this way with the Critical Discourse Analysis (CDA) that links the communicational message to property and systemic interests

"in social problems, and especially in the role of discourse in the production and reproduction of power abuse or dominance" (Van-Dijk, 1998).

It is evident that we are under a market system that not only gives us benefits but also a component of clear domination and control, although in this work we are not going to address the drama that the so-called critical thinking uses.

The PEICC implies five concepts - Politics, Economy, Information, Communication, and Culture- nothing difficult to relate to each other. Without going any further, the famous revolving doors or transfer of the politicians to the big companies and vice versa, are a clear example of the intersection between Economy-Business and Politics. This power structure will require some Information strategies to preserve itself, strategies that will develop through the media where it is both a shareholder and advertising client. The aforementioned strategies are vehicles that lead to the creation or consolidation of Cultures while the reactions of the recipients -currently prosumers- would be examples of Communication as interactivity, often foreseen by the Power itself.

From the point of view of media domination, Benito (1982) made it clear that media are used as resistance to change and to prevent the renewal of structures. Even, according to Martínez-Albertos, cited by Benito, when media influence the change it is because the new mentality has made its way to the new leaders of the system and enjoys sufficient credit; therefore, the change is completed in a way that is controlled. Media are used by the leaders. They exercise the role of controllers of the established state of affairs rather than the role of agents of subversion or unexpected change and lack of control.

Despite the current interactive digital society, this analysis continues to be valid, in our opinion, because of what we will demonstrate later in relation to the behavior of the prosumer and new control strategies by the Power.

So far, our research has been limited to describing theoretical-methodological foundations based on a Simple structural approach (SSA), which is what we usually find, in scarce amounts, in our field of study, as we mentioned. When we ask ourselves why has become as it is the society in which the SSA operates, we enter the Complex structural approach (CSA) because we are forced to go to the deepest transdisciplinary level. Barberousse (2008) collects some essential words from Edgar Morin:

"I never could, throughout my whole life, resign myself to the parceled knowledge, I never could isolate an object of study from its context, from its background, from its future. I have always aspired to multidimensional thinking. I have never been able to eliminate the inner contradiction. I have always felt that the deep truths, antagonistic of each other, were supplementary to me, while remaining antagonistic. I have never wanted to reduce uncertainty and ambiguity by force".

Therefore, if we include the PE and the PEC in the PEICC our general working method is represented as follows:
The moment we ask ourselves why has become as it is the society in which the Simple Structural Approach (SSA) is developed, we enter the Complex Structural Approach (CSA) because we are forced to go to the deepest transdisciplinarity 


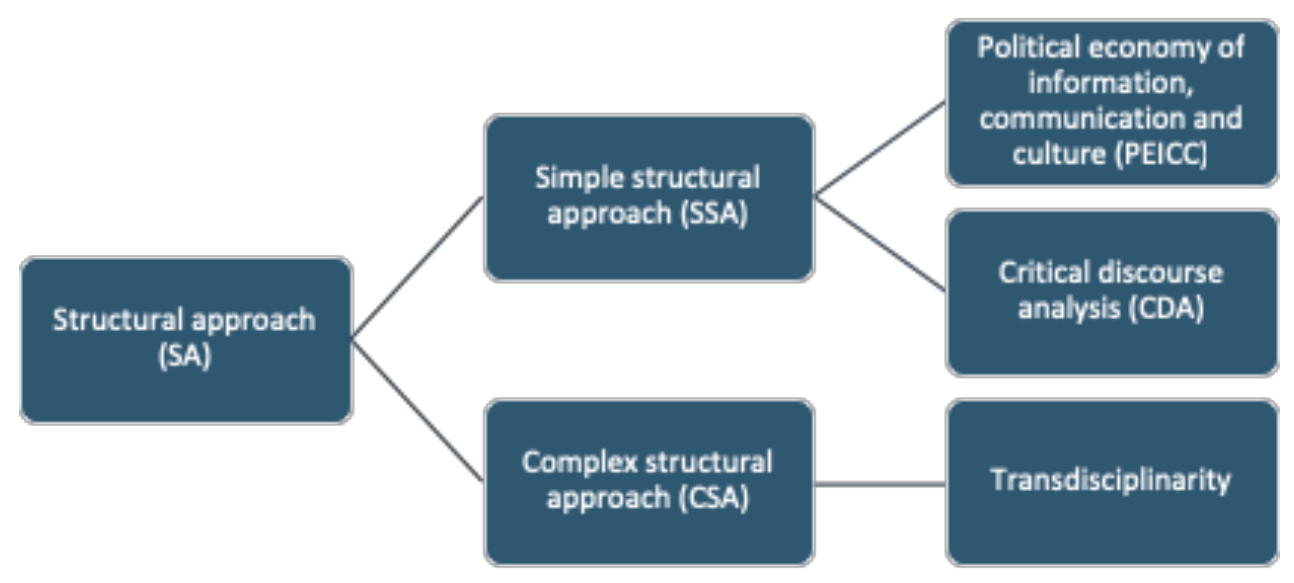

The Structural Approach (SA) is no longer exactly the epidermal method we have always known as Structuralism, not even the Poststructuralism, but it is not subjected to eternal intellectual discussions or abstruse disquisitions. It is simply common sense that tells us that it is complicated to understand something or someone if we isolate it from all the elements that make up that something or someone. The EE is the evidence that the name of a media and a media group doesn't give us any academic information without the elements that make that possible and their meanings, but that are hidden from our conscious, nor it is useful to know the name of a person or institution if we do not learn what underlies such names.

The CSA takes us to deep places. If the SSA applied to communication and journalism is sparsely cultivated worldwide, we can affirm that, so far, the CSA has a squalid presence. But this is not the place to deal with this issue or where to fully implement the CSA, although as we mentioned some of its bases will be used here.

\section{The eternal cry of critics}

Although it is an unnecessary question and perhaps a bit senseless in the academic field, we believe that we must ask ourselves this question: What is Power? Power and power. The first -Power- is the essential one, the Being of Parmenides, the one that is over time and although it changes it does not mutate in its essence; the second -power- is the conjuncture of Heraclitus. The White House goes for presidents, Wall Street, its essence and becoming, remain; Trump will no longer be president and he will return to focus on the Power he comes from, Warren Buffet, no, both united, in addition to the new and young tycoons of the Silicon Valley and the heirs of capitalism (China, Russia, India, Vietnam ...). Trump and Buffet will die physically but not so easily what they both meant.

Thompson (1998) claims that power has the capacity to influence and persuade, to exercise social control because, according to the author, it displays four types of behavioral projections: economic, political, coercive, and symbolic. The four types are interrelated with each other, these cannot be understood or exercised in isolation. Thompson classifies the media in the category of symbolic power.

Before we continue our presentation, we think it has been necessary to clarify the above premises starting -above allwith the Power and the participant empirical observation in which we have been and continue to be immersed by our position as communication professional, researcher, and university professor.

Power is Power, whatever and wherever you are: clans, tribes, early civilizations, medieval, modern or contemporary absolutism, theocracy, fascism, Nazism, communism, liberalism, neoliberalism, democracy, religion ... We can add the nuances that we want to each of the manifestations of Power, -emotionally, culturally, and scientifically- but in all of these there is a constant: the desire to preserve self -which is the obligation of all Power- it justifies the means to achieve the objective. And among those means we find Communication as a persuasive factor (Roiz-Célix, 2002), which does not require direct physical force -it does generate indirect violence- it is a soft but chronic power, which acts gradually on many occasions with effects of doubtful mental, psychic, and cognitive positivity (Reig; Mancinas-Chávez, 2013). Communication is one of the Siamese twins of Power. By becoming chronic its power transmutes from soft to hard, and dangerous for democratic coexistence and preservation of the species when it acquires clearly indoctrinating characteristics in the bad sense of the concept, in the alienating sense.

Communication is one of the Siamese twins of Power. By becoming chronic its power transmutes from soft to hard and dangerous for democratic coexistence

From the viewpoint of cultural ethics that we have described, the above may seem aberrant or logical, but that is how we believe that the subject of Power works. The so-called critical approach, which, in its most immediate origin, comes 
from Marx and the School of Frankfurt, is incomplete, it should apply itself to its own structural approach and abandon the Manichean simplification that it leads to: the perfidious capitalism, formerly industrial, now technologized and globalized, against the defenseless, manipulated, watched, controlled citizen (Faulkner, 2018). This is so, but really it is not, basic elements are missing to start completing the puzzle: transdisciplinarity and compared epistemology (Lorenz, 1980).
The so-called critical approach is incomplete, it should apply itself to its own structural approach and abandon the Manichean simplification at once that it leads to: the perfidious capitalism against the defenseless, manipulated, watched, controlled citizen

It seems that the thinking movement called critical is only interested in being the conscience of the evil neoliberal system, it appears as if it did not aspire to overcome it, to replace it, to face reality and work not only from offices and systemic studies but from the reality that, when one lives and suffers in person, as a rule, it forces him to gradually abandon his intellectual, political, ideological, and preacher points of views to take steps backwards that end up doing more harm than good to the critical methodology and its followers -those that have and those that might have- both in university and on the street. But, is it never going to seriously and universally consider why this happens? Has the critical thinking become a religion, necessary -like all- for the psychic and even material survival of some? Does the popular saying, "I wanted to change the world and it was the world that changed me," still not tell you anything nuclear or scientific? On the Internet we found this paragraph, entitled Now I realized, as we read from Anonymous (n.d.):

"When I was a young man, I wanted to change the world.

I found it was difficult to change the world, so I tried to change my nation.

When I found I couldn't change the nation, I began to focus on my town. I couldn't change the town and as an older man, I tried to change my family.

Now, as an old man, I realize the only thing I can change is myself, and suddenly I realize that if long ago I had changed myself, I could have made an impact on my family. My family and I could have made an impact on our town. Their impact could have changed the nation and I could indeed have changed the world".

The issue is also: do not tell me so many times the problem that we already know, do not talk so often about the need to be aware as we are already aware. Now, what is the next step? Or is it necessary to continue living on in the neo-whiny job of the $21^{\text {st }}$ century that, ultimately, serves to reinforce the Power that is questioned, but that ultimately legitimizes it? Later we will return to these questions, but for now let's have a look at the historical development of the issue.

It seems that the thinking movement called critical is only interested in being the conscience of the evil neoliberal system

\section{Power has always been there and has operated, essentially, in the same way}

We could extend this study through time, but it is well known that Power has been a constant throughout the history of human beings. In a book on Complex Structural Approach (CSA) that we are finishing to write now -summer of 2019-, we affirm that, as Álvarez and Caballero (1997) mentioned years ago, if the anthropologist, the sociologist, or the journalist want to study a tribe, someone or some will become the spokesperson or spokespeople for that group. It is a small power structure that proves its condition through symbolic distinctions -special clothing, totems, signs- that give that person/people a prominent rank. These distinctions are also a means of communication that sends persuasive messages. This micro-structure of socio-economic-media power will establish what is positive and negative and monitors its own safety, its conservation, observing its subjects-recipients. Place all the temporal distances you wish, all the nuances, all the appropriate changes, but the fact, in its essence, remains to this day. No matter how much interactivity occurs among the members of the species or precisely because of that. Hyperabundance of communicational activity produces a probable paralysis of knowledge, what we can call an apparent activism or the expression we used about fifteen years ago: "hibernation effect" (Reig, 1995).

We have studied the phenomenon of the omnipresence of power. Human power has tended to be prone, at various times, towards what we now call globalization. There is a historical period in which this tendency can be seen more clearly, what is nowadays globalization has its immediate roots in the Modern Age, with the creation of the Nation Estates and the beginning of the consolidation of the bourgeoisie. See the case of Figure 1.

This is a detail of a Gothic stained-glass window in the Cathedral of Saint Michael and Sainte Gudule (Brussels): "Charles $\checkmark$ being crowned by Charlemagne." Indeed, a $16^{\text {th }}$ century image shows the modern roots of what we now call globalization. Charles I of Spain and V of Germany. The discourse of religious power promoted the political, military, and economic power represented by this king-emperor. In this image, the globe with the cross on top symbolized that the king was the vicar of God on earth; the sword, the justice. The world should revolve around a single hegemonic discourse symbolized by the cross that culminates the sphere. Dissidence would have to face the sword. 
At present, the hegemonic discourse is marked by the Market called Wall Street, for example. We could call the sword NATO. In the Modern Age this message was conveyed through a stained-glass window, a type of "screen", in a wider context the cathedral, and was simultaneously articulated by an even wider Power system. Today the message is predominantly the same, and is observed on multiple screens. The interaction is greater, but mind control techniques are also much more sophisticated. One of the techniques is the theft of knowledge -through the marginalization of universal historical memory and philosophy, among other kinds of knowledge- which is replaced by infoxication, infobesity, or

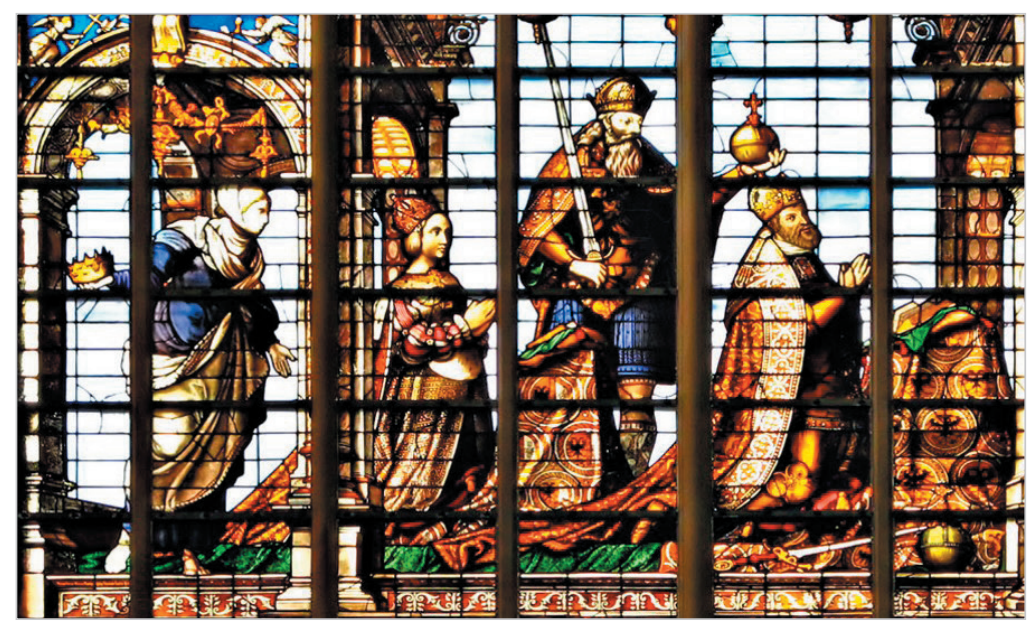

Figure 1. Cathedral of Saint Michael and Sainte Gudule (Brussels): Charles V being crowned by Charlemagne.

Source: http://www.fuenterrebollo.com/Pirineos/tarazona1.htm/ hyperinformation, as well as by the incentive to egocentricity between the species through artificial praise of innate selfishness to the human being (Reig; Mancinas-Chávez, 2018).

Current communication also abusively uses fantasy and metaphor in its evasion messages as an element that increases the meaning of the image. In the window it is specified that Charlemagne is the one who crowns Charles V, two characters that are from separate centuries, but, nevertheless, the one serves to increase the charism of the other.

\section{Current situation:}

\section{remembering -again- the} problem

In a chronological leap that we consider logical in a work of these characteristics, we reach the current socio-economic-media world, using the Structural Approach as a methodological guide. So far -and with the permission of the emerging powerswe consider the United States as the quintessential media and colonizing power. Thus Delgado (2016) developed some information that appeared in El país newspaper:

"The US concentrates the top 10 largest listed companies in the world. The rise of technology in addition to the collapse of oil and turbulence in China lead the United States to monopolize the most valuable companies on the stock market".

And he accompanied those with the table shown in Figure 2.

These are 2015 data published in 2016. In the last year, obviously, the trend had not changed, except for a significant detail. This is how Bloomberg saw it (Figure 3).

More recently, this significant variation continued and increased (Figure 4).

\begin{tabular}{|c|c|c|c|c|c|}
\hline 2014 & 2015 & Company & Country & Sector & Stock market value \\
\hline 1 & 1 & Apple & 㹃 & Tecnología & 538.403 \\
\hline 5 & 2 & Alphabet (Google) & 整 & Tecnología & 484.367 \\
\hline 3 & 3 & Microsoft & 䨌 & Tecnología & 406.577 \\
\hline 4 & 4 & Berkshire Hathaway & 를 & Varios & 298.417 \\
\hline 2 & 5 & Exxon Mobil & 㹃 & Energía & 297.707 \\
\hline 43 & 6 & Amazon & 整 & Tecnología & 290.671 \\
\hline 20 & 7 & Facebook & 整 & Tecnología & 271.539 \\
\hline 14 & 8 & General Electric & 整 & Varios & 269.715 \\
\hline 8 & 9 & Johnson\&Johnson & 俸 & Consumo & 260.752 \\
\hline 9 & 10 & Wells Fargo & 些 & Finanzas & 254.734 \\
\hline
\end{tabular}

Figure 2. The giants of the world economy in 2015. Main companies listed on the stock market on December $31^{\text {st }}$, in millions of euros. Cristina Delgado, El país, 2/1/2016.

https://elpais.com/economia/2016/01/01/actualidad/1451681862_633046.htm/

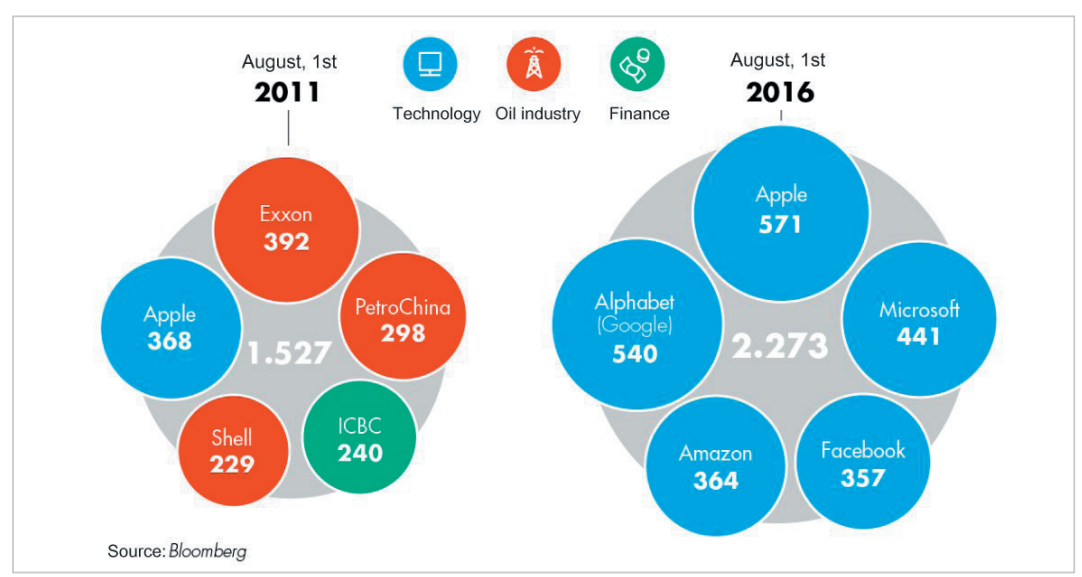

Figure 3. The 5 most valuable companies on the stock market in 2011 and 2016. Capitalization in billions of US\$, Bloomberg.

http://www.bez.es/104009798/Los-lideres-tecnologicos-conquistan-la-cima-economicamundial-.html 
Indeed, China has broken into the global financial and multicorporate scene. According to the economic newspaper Cinco días:

The big league of companies by value on the stock market is played on American soil. And the top positions are not held by banks or oil companies: the technology companies consolidate their control at the top of the table of the (listed) companies with the highest capitalization in the world. Microsoft, Apple, Amazon and Google occupy, in that order, the top four places in the ranking, while Facebook sneaks in sixth place. In the following top positions, three others ones are American (Berkshire Hathaway, Johnson \& Johnson and JP Morgan Chase). And only two Chinese, also technological: Tencent and Alibaba.

"Only two Chinese", nothing more and nothing less, we would mention to the newspaper. And they are on top of the list, from the technology sector. Is this perhaps of little importance? Where is Europe in the ranking?

The technology companies have arrived and, of course, are here to stay. Scarpellini (2019), from the El mundo newspaper, highlighted these data by limiting it to one of the most well-known companies in the sector:

- Only Facebook in 2018 had benefits of 22,112 million dollars (about 19,265 million euros).

- The social network increased its profits by $39 \%$ in 2018 and by $9 \%$ the number of daily active users worldwide.

- More than 1,520 million users.

- Had a turnover of 55,838 million dollars (about 48,650 million euros), 37\% more than the 39,942 million of 2017 (about 34,800 million euros), which helps to keep at bay -at least for now- the swirling rumors about the social network decline due to the departure of the youngest people mainly caused by data leaks between Facebook and Cambridge Analytics in 2018.

- The business owner -Mark Zuckerberg- has insisted on his bet for 'Stories', an option that he believes will become something bigger than the traditional Facebook wall where users publish their photos and stories. Between Instagram and WhatsApp, also owned by Facebook, more than 1,000 billion of these digital stories are shared daily.

- This and the emphasis on advertising through mobile phones, which represented a chilling $93 \%$ of the total advertising revenue in the last quarter of 2018, exceeding 89\% for the same period of 2017.

Here is the Power. But it is incomplete. In recent years we estimate that a competition is taking place, and at the same time also collaboration, between the generations that are the protagonists of Power. The younger generation -the one of Silicon Valley, to name it more or less adequately- is proving to be more aggressive and competitive than their "teachers" and ancestors. They are not limited to technology, in the traditional sense, but are applying this technology to the financial world and the daily world of monetary circulation. And of course, they are investing in communication and allying with the old owners of this and other sectors of production. Let us add to this that their components are authentic engineers of "tax savings", everything -or almost everything- within the law, of course, despite the fact the EU and specific countries have sometimes imposed sanctions on them. Remember what we affirm: Power has the obligation to preserve itself and then the end justifies the means of doing so:

"The large global technology companies, such as Microsoft, Amazon, Google, Facebook or Apple, have found in Europe a market where they can comfortably place their high added value products and, through relatively sophisticated tax practices, save the payment of taxes that it would correspond to the income they get. The latest known calculations, referring to the year 2017, indicate that while in that period they obtained net benefits greater than 11\% compared to the previous year in Spain, they paid 8\% less; and that the income statements, made up by corporate tax avoidance structures, are three to four times lower than the real ones in Spanish territory" (El país, 2019).

Warren Buffet and Bill Gates are owner partners of the holding company headed by Buffet: Berkshire Hathaway, an investment firm that owns shares, among many others, of Coca Cola, Comcast (owner of NBC), Gannet (media group), General Electric, Moodys, Procter \& Gamble, The Washington Post and lately also of Amazon (Martínez-Bernal, 2019). The youth and talent of Gates (63 years old) and Mark Elliot Zuckerberg (35 years old), together with Buffet's seniority ( 89 years old) and of his right hand, Charlie Munger (95 years old) who's succession has already been prepared. Here is a paradigm of the new Power of the $21^{\text {st }}$ century. 
At the same time as is well known, these large companies are allied with the great world bank:

"The tech giant Amazon, the 'investor arm' of the billionaire Warren Buffet, Berkshire Hathaway, and the American bank JP Morgan have signed an association agreement under which they will create an independent health care company that aims to reduce the costs of medical care and improve the services offered to its employees in the United States" (Europa Press, 2018).

Except for Amancio Ortega, the rest of the names that appear in Figure 5 have properties in the world of communication, but not exclusively in this sector but in all those in which they consider that their money can yield positively. It is clear that the "acclaimed" The New York Times and The Washington Post are not anti-power, they are not against the Power, but are part of it, although the official discourse of the market and journalism will always affirm that they are free. The experts that have been cooks before friars (journalists before professors) will not deceive us, but they will mislead a wide layer of population, university people or not. The discourse, from the self-conservative obligation of Power, is not misguided.

However, a magnificent documentary called Shadows of liberty (2012), focused on the US communication world, where Professor McChesney played a leading role, warned us:

- Five large groups control $90 \%$ of the US media.

- This concentration of media is jeopardizing press freedom.

- Several experts -journalists and other communication professionals, high-level professors and other specialists- denounced the situation.

- There exist censorship and cover-up practices.

The documentary -very well known in our field of work- included other very interesting information, but we take only the above four facts.

If, as a didactic method, we deviate a bit from the socio-economic context and enter fully into the field of communication dynamics, we have can develop a series of examples that offer a quick overview of current trends. Let's have a look at a ranking of the main communication groups in the world (Table 1).

There is interesting news: for the first time in the communication history two Chinese brands are among the world's largest media groups: CCTV (TV) and Baidu (the Google of China, because in China Google is blocked by censors). NTV is a Russian television corporation and Sanoma is a media group from the Nordic countries of Europe, while Yomiuri and Asahi are "veterans" from Japan. There is only one Latin American mega group, O Globo (Brazil). The rest of the names of the list consist of technology and other US firms, plus some European ones. The US control is evident, but, as in other areas of pro-
Table 1. Top 30 media companies.

\begin{tabular}{|l|l|l|l|}
\hline \multicolumn{1}{|c|}{ Rank } & \multicolumn{1}{|c|}{ Company } & \multicolumn{1}{c|}{ Company } \\
\hline 1 & Google & 16 & Asahi Shimbun Company \\
\hline 2 & Walt Disney Co. & 17 & Grupo O Globo \\
\hline 3 & Comcast & 18 & Yahoo! \\
\hline 4 & $21^{\text {st }}$ Century Fox & 19 & Full Media Holdings \\
\hline 5 & CBS Corporation & 20 & CCTV \\
\hline 6 & Bertelsmann & 21 & Microsoft \\
\hline 7 & Viacom & 22 & Hearst Corporation \\
\hline 8 & Time Warner & 23 & JCDecaux \\
\hline 9 & News Corporation & 24 & Yomiuri Shimbun Holdings \\
\hline 10 & Facebook & 25 & Mediaset \\
\hline 11 & Advance Publications & 26 & Axel Springer \\
\hline 12 & IHeartMedia & 27 & ITV plc \\
\hline 13 & Discovery & 28 & ProSiebenSat.1 \\
\hline 14 & Baidu & 29 & NTV \\
\hline 15 & Gannett & 30 & Sanoma \\
\hline
\end{tabular}

Source: The Daily Television,13/5/2015.

http://thedailytelevision.com/articulo/research/zenithoptimedia-google-mayor-dueno-demedios-del-mundo-por-lejos 
duction and human work, the "empire" is no longer the only one in this domain, aggressive competitors of similar weight have come out, something that will only continue to increase in the future.

If we have a look at other places on the planet, for example, the Islamic-Arab world, we observe an imitation of the West, limited by some cultural peculiarities of that area. The media groups concentrate enormous power and connections with sectors other than communication, with governments and with Western groups. As Ortega-Pérez (2019) has written in his doctoral thesis, if we take the case of Kingdom Holding Company (KHC) we find one of the few Saudi companies that does not have the Saudi government as a shareholder, unlike other companies in the kingdom, such as Sabic (70\% owned by the government) or Saudi Electricity Company (74\%). KHC is the business core of a Saudi magnate, Alwaleed bin Talal. On the 2016 Forbes list of the world's largest companies, this conglomerate of Saudi origin was ranked number 1,779 , with an estimated capital of US $\$ 12.2$ thousand million. Alwaleed bin Talal has invested in Apple, Twitter, GM, Citygroup, $21^{\text {st }}$ Century Fox, etc. In 2018, he talked about his investment interest in Netflix and Amazon.

Through KHC, with 95\% ownership, bin Talal has positioned himself as an investor in almost all sectors, including financial services, real estate, hotels, petrochemicals, telecommunications, aviation, commerce, and media. The remaining $5 \%$ of the conglomerate is distributed among various Saudi and Western shareholders. Those known are, or have been (given the lack of transparency in this type of data) La Française Asset Management SAS (0.81\%), Talal bin Ibrahim Al-Maiman (0.15\%), Mellon Investments Corp. $(0.0003 \%)$, Caisse des Dépôts (0.8074\%), Shadi Sadeek Sanbar (0.1424\%), and Saleh Ali Saud Al-Sagri (0.0482\%).

All these companies -from here and there- are obliged to get on with each other much more in the future, like those in other sectors that they are linked to. It is, in a few words, the announcement of a world government where good journalism faces a complicated future, among other factors because entertainment and great alliances have arrived (Figure 7 and Table 2) to launch millions of messages to receivers for evasion and much of journalism is entering this trend.

Table 2. Audiovisual platforms, 2018-2019

\begin{tabular}{|l|l|l|}
\hline \multicolumn{1}{|c|}{ Name } & \multicolumn{1}{|c|}{ Country } & Alliances \\
\hline Netflix & EUA & Telefónica, Orange, Vodafone \\
\hline HBO & EUA & Time Warner \\
\hline Prime Video & EUA & Amazon \\
\hline Premium & EUA & YouTube \\
\hline Huawei Video & China & $\begin{array}{l}\text { Atresmedia, RTVE, Entertainment One (eOne), Zoomin, Inverleigh, Daluqiao, Thema (part of the } \\
\text { French group Canal+ for content) }\end{array}$ \\
\hline Sky/Disney Video & EUA & ABC, Disney, News Corporation \\
\hline
\end{tabular}

In a few lines we have described Power, for good, for evil and all the gray tones in the middle. We do not have space to comment on the data and images, but we believe that those are quite enlightening. However, the question is not over yet, how will Power be in the next years of this $21^{\text {st }}$ century? 


\section{Artificial intelligence: identity and problem of the $21^{\text {st }}$ century}

The current and future situation is characterized by what has just been noted in the previous section and also the absolute preeminence of the technological, one of its central manifestations is already artificial intelligence (AI) with all the joys and headaches that it is causing us and will continue to cause us. Fernández-Enríquez (2019) indicated that all Spanish public and private investment in research in one year is equivalent to the amount Apple invest in the same period of time. The US company has already invested about 11,000 million euros and is expected to end the year spending 14,400 million in R\&D to compensate for the drop in sales of iPhone Spain, which seeks to recover to pre-crisis levels. Apple invested 14,063 million in 2017 and it is estimated to have reached 14,900 million in 2018 , according to the Cotec Foundation. Countries often reduce their investment in innovation in critical times, but nations like Japan or China opted for the contrary: to invest more to get out of isolation and transform their production model (Fernández-Enríquez, 2019).

The current and future situation is characterized by the absolute preeminence of the technological, one of its central manifestations is already artificial intelligence (AI)

In this same direction, what does the Chinese giant Huawei forecast (which with $20 \%$ of the mobile market is already the second largest producer after Samsung)? At the XV annual congress Huawei Global Analyst Summit 2019 (HAS) presented the report Global industry vision. Touching an intelligent world in which scenarios are projected about the future and the role that information and communication technologies will have in society in 2025 (Huawei, 2019). It also described the latest developments, business practices and solutions in the field of services in the cloud: 5G, internet of things (loT), artificial intelligence (AI), and digital transformation.

"Global Industry Vision (GIV) is a plan for the future development of the ICT industry based on statistical analysis and scenario projections. In 2025 we will be in the era of 'Intelligence +'"says the tech giant.

Some Huawei forecasts:

- Domestic robots will be in 14\% of the homes of the G8 countries thanks to the advances in the science of materials, perceptual artificial intelligence, and network technologies.

- Smart automation will adopt more dangerous, repetitive, and high-precision tasks, which will have a greater impact on safety and productivity. In the industry there will be 103 robots for every 10,000 employees.

- $97 \%$ of large companies will have adopted Al, which will result in a reduction of costs and barriers for scientific experimentation, innovation, and art. This will allow more room for creation.

$-85 \%$ of commercial applications will be in the cloud, which will allow greater collaboration, exchange of resources, stronger global ecosystems, and greater productivity.

- $58 \%$ of the world's population will have access to $5 \mathrm{G}$ technology, with a large increase in the data transmission speed.

- The digital economy will be worth 23,000 billion dollars.

- Intelligence + technology will be present in all industries in one way or another, in consequence the volume of shared data will grow exponentially.

- The annual volume of global data will reach $180 \mathrm{ZB}\left(1 \mathrm{ZB}=1,000\right.$ billion $\mathrm{GB}=10^{21}$ Bytes).

There is a whole range of warnings and precaution announcements originated from various studious and knowledgeable voices of Al. Beware of destructive robots, which are already a reality, with the manipulation of pixelation, with intelligent speakers, with autonomous cars, and endless initiatives that bring us unquestionable advantages, although these also bring another side of the coin (Johnson, 2019). Nevertheless, from the critical thinking point of view it seems that what affects and worries the public the most is a surveilled society. Del-Castillo (2018), notes:

"It is often said that algorithms know everything about you. In fact, it's not quite like that: in the era of apps, if you don't know who programs your tools or what their goal is, you are the one that is programmed."

"In the Chinese city of Xichang there is the largest cockroach farm in the world with 6,000 million cockroaches in it that, if these escaped, would cause a huge ecological disaster. But these don't: Artificial Intelligence keeps them happy and content inside, controlling 80 variables of their life so that the only thing that cockroaches have to think about is growing and reproducing. The machine does not know anything about each one of them, nor is it interested. It only predicts their behavior and anticipates their needs for food, temperature or humidity before directing these to their particular slaughterhouse and use their supposed medicinal properties."

"Citizens of developed countries usually say that digital platforms know everything about us. Actually, it is not quite like that. A machine does not know anything about us, nor is it interested. It knows us, but not how our mother or our best friend knows us. It knows us like the Chinese farm knows its cockroaches. It needs information about us, but only in order to predict our future needs and be able to anticipate them."

Rushkoff (2009) and Del-Castillo (2018) agree that social networks are not effective tools for a different political exchange, since these are "captured" and "monetized." In 2014, López-Londoño, echoing an analysis published in the newspaper El país in 2013, wrote:

"In recent months, the scope of mass surveillance has become a well known fact. With a few mouse clicks, the 
Government can access our mobile devices, our email, our social networks and our Internet searches. It can keep track of our political inclinations and activities and, in collaboration with Internet provider companies, it can collect and store all our data and, therefore, predict our consumption patterns and our behavior. All human beings have the right not to be observed nor disturbed in their thoughts, their personal environments nor their communications. This fundamental human right has been annulled and removed of content because of the misuse of technological advances by Governments and companies that carry out massive surveillance programs. A surveilled person ceases to be free; a surveilled society ceases to be a democracy. If we want our democratic rights to remain valid, it is necessary that these be respected in the virtual space as well as in the physical space".

Still earlier, Mattelart (2009) wondered:

"how sociotechnical systems have been implemented that have expanded the area of competence of the inquisitorial technologies of the individual and collective freedom and that are responsible of the police or military genealogy (...). Unable to combine the yearnings of freedom with the desire for security, the network heads of the world-system are shielded in the energetic management of inequalities instead of declaring war on machines that promote them and to attempt to reestablish the badly damaged solidarity systems".

Here, Mattelart shows an enormous sensitivity, questioning a behavior of the Power. Later on we will return to this briefly.

\section{Journalism also exists (or so it claims)}

Within the socio-economic-media context that we have just exposed, journalism is found struggling to adapt to new circumstances, but at the same time trying to avoid losing its essence. These are the current struggles of modern journalism:

1) Try to be against-Power, not an element of Power, as we have seen.

2) Derivation of the above, journalists with their own sources, critical capacity -questioning everything-and great cognitive training.

3) Motivate that Power does not feel comfortable through a transgressive and formative journalism of the receiver, not indoctrinating.

4) Give voice to those who have less chance of being heard.

5) Allow reality to ruin a good report.

6) Develop as much as possible the why of the journalistic opening line. In our case, the question, "Why?" has led us to the Complex structural approach.

What does journalism find as an obstacle to its practice?

- fake news,

- hook news,

- intrusion of all kinds,

- spectacularization of the profession,

- some journalists have the urge to be in the limelight...,

all of which are added to what, in Spanish journalism is known as the " $\mathrm{P}$ " obstacles as all these concepts start with this letter):

- media ownership,

- advertising,

- politics,

- accelerated production of the news which requires to execute several jobs in one (news search engine, editor, layout artist, proofreader, computer expert...),

audiences that do not exactly ask for all the points of view of an event but those that want to read or listen to reaffirm their convictions and that do not complicate their existence. And finally,

- journalists with interests closer to their companies than to journalism.

In addition, journalism clashes with a phenomenon derived from digital journalism: if companies before wanted to sell paper, now they intend to sell time, that is, to ensure that the receiver is "hooked" (engagement) as much as possible to media, as it has always been the case with TV. This translates into higher revenues, hence the clickbait news that has broken with the theory of journalism, in the sense that the receiver must learn the essence of the information by just reading the headline and the lead.

Where is $21^{\text {st }}$ century journalism headed? In the first place, even the digital newspaper is no longer as necessary as it was some years ago (no need to tell about the paper version, which will become a necessary relic). There are websites and information services derived in large part from the digital press that convert utensils such as smartphones into real terminals of information agencies with the advantage that the newsis really diverse because citizens can receive information offices of all the trends they want. However, the systematized reading of newspapers -if possible more than two and from different ideologies- is still very important, although we still have to make continuous assessment about the 
present and future results of the digital press, especially of the digital native one that does not depend on large-scale communication groups.

Numerous professionals have studied journalism of the future: Baron (2017), director of The Washington Post, has released four predictions that must be addressed from the media:

- First, mobile technology will take over. Media will have to focus exclusively on the mobile experience.

- Second, media must have a deep knowledge of social networks.

"In these networks people talk to each other. If you want to know what people worry about, you will have to

listen better and listen more frequently. And if you want to listen, go where people talk".

- Third, it is impossible to predict what the dominant news brands will be in the future. Newcomers can sink the media establishment: BuzzFeed was founded in 2006, Huffington Post, in 2005. They are now important actors in the media universe, in the US and internationally.

- And fourth: advanced technology will be key to our success.

"We have to be leaders. If we are technological laggards, we will lose. Media will have to have high tech staff. We will have to create new attractive products for readers and advertisers, and do it with agility".

In its report Predictions for Journalism for 2019, the Nieman Lab, Harvard (2019), draws a less promising picture for the future of the profession, and suggests:

- More information saturation by readers.

- The diminishing role that media mediation plays.

- Multiplication of fake news.

https://www.niemanlab.org/collection/predictions-2019

This report includes this opinion:

"The challenge for journalism in the years to come is to reinvent itself around something other than news, whilst resisting the seduction of propaganda and entertainment" (Hossein Derakhshan, MIT researcher).

From our point of view, we must always pay attention to those authentic emperors of sale that are in the USA, but without forgetting that there is a qualitative base behind journalism and that minority communities also have the right to live, that not everything can be a quantitative approach of the market. This is what we hold and what the critical thinking pursues, only that the latter has fallen hopelessly into mysticism and an important cognitive and scientific deficit, caused by observing reality diffusely and not acting with much more factuality, up to the standard the enemy sets.

\section{Conclusions and final discussion: of how the citizen, heir to the good savage, was contaminated with evil and ignorance by extraterrestrial capitalism}

Although this article is one of those works that are called scientific and perhaps we should express ourselves with excellent and academic words, we are going to allow ourselves to write close to fiction. After all, scientific journals in their editing standards request expository clarity, something that seems elementary since clarity is not at odds with rigor. We use this editorial line when we focus a little more on our objections to the so-called critical thinking, something that we began to develop at the beginning of this work.

For decades we have identified ourselves with an idea: the market has brought us and continues to bring us undoubted positive aspects. But it is the essential cause of the symptoms of self-destruction and pathologies that human beings from the so-called elites and, by extension, not a few of the humans who follow them in the social pyramid, suffer today. However, we also believe that there is a palpable fact, for the moment and unless the human brain is walking towards much more solidary situations: the market, capitalism, is not just a cultural manifestation of human beings, but it is the human being himself in biological evolution.

The entire structure of Power that has just been analyzed above is guided by the desire to sell, to market -as alwaysand by the exploratory drive of the human, both factors are components of a tendency to adapt to the environment not to seem (the other question is if the adaptation attempt is successful). However, when we read the simplest and most abundant positions of critical thinking and its political-ideological manifestations -that the same critical thinking is forced to betray again and again when it is involved in the cyclical political power- a kind of children's story comes to mind:

Once upon a time the citizens and subjects of the $21^{\text {st }}$ century, called "the people", heirs of the innocence of the good savage. Suddenly, Earth is invaded by a legion of flying saucers coming from extraterrestrial places. The doors of the strange ships open and from them descend perfidious beings called capitalists, liberals, and neoliberals, who break in to eliminate and manipulate the minds of the kind "people." And the kind people, in their innocence, fall into the networks of those strange beings who have not been born on our planet but in remote places of the universe and, as they are more intelligent than us, they make us their vassals even though at the same time they deliver us defense tools not to be.

Indeed, it is a childish vision or, at least, short-sighted, incomplete, that becomes religion, in belief, that is needed by some as much as others need to believe in Wall Street, in the Bible or in the Virgin of Guadalupe, with a difference: the 
believers in these three totems are more or less united while the observers of critical thinking -which deify the "people" and, within them, the poor [they do, in our opinion, Faulkner (2018) and González-Pazos (2019)] they are scattered throughout the world, proclaiming the evil of the aliens without having achieved almost anything in favor of the people since in 1989 a crowd demolished the Berlin Wall despite the fact they had been developing theoretical summits for solidarity and justice since the early 90s (González-Pazos, 2019). There is, therefore, one more problem, the human now suffers from two problems: the evil that comes from the aliens and that which comes from his earthly opponents.

What would these opponents do if they had to exercise Power instead of being spectators of good deeds and misdeeds of Power? Would they give up a surveilled society? Then the aliens would defeat them. Would they give up an accumulation of both media and socioeconomic power in general? Then aliens would still devour them. What do they call equality? I think that the society of the one thousand million flies that could not be mistaken and that is why it was convenient to follow their example and immerse themselves in the waste, an immersion that despises the full freedom of human individuality. Draft animals pull the cart, but they would not do so if someone had not invented the wheel and everything that allows the cart to be a cart and if someone had not taken the risk by making the products that the cart transports after they were manufactured. There is no initiative without individuality, previously there was no production without employers and workers, now it is possible without workers, but not without the human initiative of a small minority specialized in business and various technologies, as well as in social sciences and humanities.

The Alexandrian Empire would not have existed without Alexander the Great, when he died, the empire disintegrated; Athenian democracy of the fifth century BC had its roots about a century before, thanks to the initiative of a nobleman, Solon, who rebelled against his own noble estate, oppressor of the "people." Solon's laws paved the way for Pericles, but Athenian democracy ended up being dominated by Pericles and "lobbies" of power, caused, for example, to the absenteeism and disinterest of the "Democrats", something similar to what is happening today. Therefore, it has been overrated.

It is not that "people" are a useless entity, it is that the simplistic critical approach has arisen from the Rousseaunian doctrine - which Marx inherited- and does not look around, that way it has an important mission: it is awareness of Power, but, for the moment, it is far from being Power. It idealizes the "people" (Faulkner, 2018), which must be respected in their rights, but perhaps the typical and topical critical approach does not know -or does not want to know- that human beings, when they cause changes by voting or revolutions, they do not do it in favor of the collective but for themselves, for their individual preservation and their genetic descendants plus some cultural element that is very special for the prolongation of the individual subject. It is difficult to accept this, so it is more comfortable for the psyche to relate to mysticism and Manichaean dualism.

If we want current empirical examples, we have them: Siryza in Greece, Podemos in Spain, the latter a living example of how humans want to be something emotionally positive and to put them back in place. Actually, they leave their mark, but it also strengthens the Power that has allowed them to act, to some extent.

Power is strengthened with the so-called cyber-activism. If the Power itself has created something new in History such as the prosumer, what can be done now to control again the citizen who has "weapons" with which to agitate his inventors? It must accomplish these actions (it is complying with them):

- From our point of view:

1) Snatching the method to understand Life and History. It is the structural method that remains in the hands of the elite.

2) Through freedom across the digital world. The more digitalization without method, the less knowledge.

3) Through necessary illusions: "I am free and I live in democracy."

4) Through the anti-system dynamic. The system builds seemingly anti-system speeches.

5) Stimulating the activity of nature or human condition that is selfish, not social. The market and the digital world are ideal for this.

- Alternative? Is there one?

For now there are no real, articulated, globalized alternatives. The creative economy, solidarity trade, alternative communication..., yes, all that sounds good, but -with its ups and downs, anachronism, little preparation and scarce persistence and articulation- it has made little impact to those who for centuries have been planning self-preservation strategies. The world is going towards the Artificial Intelligence market, not towards another paradigm. "People", in general, play, they neither think nor act, play, divided by postmodernity, by gregarious individualism, by the pose, by empowerment propagated by paternal and teaching education, by posturing that technologies allow. If someone intends to win this war, they must start from this fact, not from imaginary ones. 
Imaginary ones speak of the evil aliens who dominate and manipulate via media. However, nobody goes down to the arena to face them, in the market, native digital newspapers and certain websites do confront them, but what will happen to these media? How to live in a world created by Power fighting that Power and even trying to be neutral? Are there enough human elements, with perseverance, liquidity and preparation to accomplish it? Attempts are made by governments called leftist in Latin America (Serrano, 2016), but they end up being evicted from power by the same people that elected them. Goodbye to their solidarity communication policies, goodbye to their confrontations with the International Monetary Fund, goodbye to their wishes for liberation that are theirs, yes, but are they sure that these are also of the "people" or do they need such idea to give themselves a mission that provides meaning to their life and thus turns it into existence? Who are the aliens really? Neither one nor the other, they all are human beings in conflict with life and death, individual and as a species.

When García-Gutiérrez (2016) demonizes digital capitalism and speaks of "the digital offensive of capitalism", he insists on what here we will call mystical-biblical vision of angels and demons; the latter abuse their digital power against the poor little digital citizen angel whom they turn into a cognitive "disable" -states García-Gutiérrez-, but in reality what exists is a period of market expansion, a phase that pursues preservation as power, as is its obligation and would be the obligation of any power, and in that dynamic logical excesses derived from the human nature are committed.

If this or other authors wish to alleviate the problem, in addition to being spectators, they must build a parallel market with different ethics and morals, and this can be accomplished with a worldwide interaction of organizations that call themselves alternatives for, then, to achieve political power democratically and risk the consequences because the real power will not stand still waiting to be evicted or limited because, as Elías says (2015),

"we live in a cybereconomy in which who governs the world is who knows how to program forever to win more in the virtual game".

Elías is also critical of the negative edges of this fact, but he is not an author concealed in a rhetorical and very repetitive criticism, but he faces the reality of a species in evolution that goes through key but natural moments, there are no aliens here, what there is, is a species that, in its most technified elements, has reached a specific historical stage, in accordance with Hegel's dialectic. And it has achieved it from human causes derived from its desire to last, which includes its exploratory drive and its aggressive-violent drive, among others.

To critical thinking, maybe make life complicated and abandon its simplifications agitates it or might consider it something neoliberal or "right-wing", but it must complete/reestablish once and for all its vital and academic methodology and reach the Complex Structural Approach (CSA), which is nothing new. Not to go on at great length, already Comte, in the eighteenth century, spoke of "social physics," as Martínez-Quintana (2017) collects,

"who had as object of study the social phenomena that were observed with the same spirit that was applied to astronomical, physical, chemical and physiological phenomena, and that obeyed certain invariable natural laws that had to be discovered".

Disturbing, but why should we fear this and other similar perspectives? We think these are essential to understand human history and, within it, power, communication and journalism. Perhaps is the critical thinking afraid of freedom? Because only by understanding from the deepest one can begin to be free.

\section{Referencias}

Almiron, Núria; Reig, Ramón (2007). "The communications research in Spain: the political economy epistemological approach". American communication journal, v. 9, n. 2, Summer.

http://ac-journal.org/journal/2007/Summer/5CommunicationsResearchinSpain.pdf

Álvarez, Tomás; Caballero, Mercedes (1997). Vendedores de imagen: los retos de los nuevos gabinetes de comunicación. Barcelona: Paidós. ISBN: 9788449303708

Anonymous (n.d.). Ahora me di cuenta.

http://www.bama.org.ar/sitio2014/sites/default/files/_archivos/merkaz/Jomer_on_line/rh_mundo_varios.pdf

Barberousse, Paulette (2008). “Fundamentos teóricos del pensamiento complejo de Edgar Morin”. Revista electrónica Educare 2008, v. XII, n. 2.

http://www.redalyc.org/articulo.oa?id=194114586009

Baron, Martin (2017). Predicciones sobre el periodismo del futuro, 26/1/2017.

http://conversacionescon.es/conversaciones-martin-baron

https://www.youtube.com/watch?v=F5MPhaqw8D8

Becerra, Martín; Mastrini, Guillermo (2009). Los dueños de la palabra. Acceso, estructura y concentración de los medios en la América latina del Siglo XXI. Buenos Aires: Prometeo Libros. ISBN: 9789875743465

Benito, Ángel (1982). Fundamentos de teoría general de la información. Madrid: Pirámide. ISBN: 8436801830 
Birkinbine, Benjamin J.; Gómez, Rodrigo; Wasko, Janet (2017). Global media giants. New York: Routledge. ISBN: 9781 315682334

https://doi.org/10.4324/9781315682334

Campos-Freire, Francisco (2012). "Los grupos de comunicación de Europa se concentran en la Agenda Digital 2020”. Razón y palabra, n. 79, 2012, 45 pp. https://www.redalyc.org/pdf/1995/199524411056.pdf

Cardoso, Ciro F.; Pérez-Brignoli, Héctor (1976). Los métodos de la historia. Introducción a los problemas, métodos y técnicas de la historia demográfica, económica y social. Barcelona: Crítica. ISBN: 8474230039

Castells, Manuel (2009). Comunicación y poder. Madrid: Alianza Editorial. ISBN: 9788420684994

CIC. Cuadernos de información y comunicación (2006). Economía Política de la Comunicación, v. 11. Madrid: UCM. ISSN: 1135-7991.

https://revistas.ucm.es/index.php/CIYC/issue/view/CIYC060611

Curran, James (2005). Medios de comunicación y poder en una sociedad democrática. Barcelona: Hacer. ISBN: 8488711743

Del-Castillo, Carlos (2019). "Sociedades en libertad vigilada". Eldiario.es, 31/12/2018.

https://www.eldiario.es/tecnologia/Sociedades-libertad-vigilada_0_852165002.html

Delgado, Cristina (2016). “EE UU concentra las 10 mayores empresas cotizadas del mundo”. El país, 2/1/2016. https://elpais.com/economia/2016/01/01/actualidad/1451681862_633046.html

El país (2019). “Evasión tecnológica. La eurozona está obligada a imponer una norma fiscal homogénea a las grandes corporaciones". Editorial. El país, 28/3/2019.

https://elpais.com/elpais/2019/03/27/opinion/1553707148_272105.html

Elías, Carlos (2015). El selfie de Galileo. Software social, político e intelectual del siglo XXI. Barcelona: Península. ISBN: 9788499424248

Europa Press (2018). "Amazon, Berkshire Hathaway y JP Morgan crearán una empresa de servicios de salud”. Expansión, $1 / 01 / 2018$.

https://www.expansion.com/empresas/2018/01/30/5a70760fe2704eb84c8b45cc.html

Faulkner, Neil (2018). A radical history of de world. London: Pluto Press. ISBN: 9780745338057

Fernández-Enríquez, Iván (2019). “Toda la inversión española pública y privada en investigación equivale a la que hace Apple en un año". Eldiario.es, 12/08/2019.

https://www.eldiario.es/economia/Apple-invertira-innovacion-economia-espanola_0_928457208.html

García-Gutiérrez, Antonio (2016). Fuentes digitales. Totalitarismo tecnológico y transcultura. Salamanca: Comunicación Social Ediciones y Publicaciones. ISBN: 9788415544524

García-Santamaría, José-Vicente (2016). Los grupos multimedia españoles. Análisis y estrategias. Barcelona: UOC. ISBN: 9788490644911

González-Pazos, Jesús (2019). Medios de comunicación. ¿Al servicio de quién? Barcelona: Icaria. ISBN: 9788498888997

Herman, Edward; McChesney, Robert W. (2001). Global media: The new missionaries of global capitalism. A\&C Black. ISBN: 9780826458193

Hesmondhalgh, David (2019). The cultural industries. London: Sage. ISBN: 9781526424099

Huawei (2019). “Global industry vision. Touching an intelligent world”. In: Huawei Global Analyst Summit 2019 (HAS). https://www.huawei.com/minisite/giv/Files/whitepaper_en_2019.pdf

Johnson, Dave (2019). "11 de las tecnologías actuales más inquietantes por las que deberías estar preocupándote". Business insider, 12 agosto 2019.

https://www.businessinsider.es/11-tecnologias-tremendamente-inquietantes-existen-hoy-dia-470537?page=3

Labio, Aurora (2006). Comunicación, periodismo y control informativo: Estados Unidos, Europa y España. Barcelona: Anthropos. ISBN: 9788476588000

López-Londoño, Luis-Miguel (2014). Sociedad de la vigilancia. Redes y lugares de información. Universidad de Manizales, Programa de comunicación social y periodismo. Año 17, v. 12, n. 1.

Lorenz, Konrad (1980). La otra cara del espejo. Ensayo para una historia natural del saber humano. Barcelona: Plaza \& Janés. ISBN: 9788401411670

Mancinas-Chávez, Rosalba (2016). "Fundamentos teóricos de estructura de la información". Cuadernos artesanos de comunicación, n. 106, 153 pp. Universidad de La Laguna. 
http://www.cuadernosartesanos.org/2016/cac106.pdf

Martínez-Bernal, Pablo (2019). "Los valiosos mensajes de Warren Buffett a los accionistas. Expansión”. Expansión, 6/5/2019.

https://www.expansion.com/mercados/2019/05/06/5ccfe5bc268e3e4b1a8b45fc.html

Martínez-Quintana, Violante (2017). ¿Cómo funciona la sociedad? La mirada científica de la sociedad. Madrid: Ediciones Académicas UNED. ISBN: 9788494698095

Martínez-Vallvey, Fernando; Núñez Fernández, Víctor (coords.) (2016). La comunicación y su estructura en la era digital. Madrid: Centro de Estudios Financieros. ISBN: 9788445432907

Mattelart, Armand (2009). Un mundo vigilado. Barcelona: Paidós. ISBN: 9788449321917

McChesney, Robert W. (2013). Digital disconnect: How capitalism is turning the internet against democracy. New Press. ISBN: 9781595588913

Mosco, Vincent (2006). “La economía política de la comunicación: una actualización diez años después”. CIC. Cuadernos de información y comunicación, v. 11, pp. 57-79.

https://revistas.ucm.es/index.php/CIYC/article/view/8118

Muñoz, Blanca (2005). Cultura y comunicación: Introducción a las teorías contemporáneas. Madrid: Fundamentos. ISBN: 8424510372

Nieman Lab, Harvard (2019). Predicciones del periodismo para 2019 (Predictions for journalism), 2/1/2019. https://dircomfidencial.com/medios/estas-son-las-tendencias-del-periodismo-para-2019-20181231-0403

Ortega-Pérez, Ana-María (2019). La estructura de la información en Arabia Saudí en el contexto del sistema mediático en los países árabes. Tesis doctoral. Universidad de Sevilla (España). Directores: Ramón Reig y Rosalba Mancinas-Chávez. Inédita.

Puentes-Rivera, Iván; Campos-Freire, Francisco; López-García, Xosé (2018). Journalism with a future. Oporto: Media XXI. ISBN: 9789897291968

Quirós, Fernando (1998). Estructura internacional de la información: el poder mediático en la era de la globalización. Madrid: Síntesis. ISBN: 8477386064

Reig, Ramón; Labio, Aurora (eds.) (2017). El laberinto mundial de la información. Estructura mediática y poder. Barcelona: Anthropos. ISBN: 9788416421671

Reig, Ramón; Mancinas-Chávez, Rosalba (2018). "La raíz del poder y la comunicación mercantil actual en una imagen”. En: María del Mar Ramírez-Alvarado, Ángeles Martínez-García (coords). 50 imágenes para entender La comunicación en el siglo XX. Valencia: Tirant lo Blanch. ISBN: 9788417203559

Reig, Ramón; Mancinas-Chávez, Rosalba; Nogales-Bocio, Antonia-Isabel (2017). "Enfoque estructural complejo: propuesta metodológica desde el periodismo". Estudios sobre el mensaje periodístico, v. 23, n. 1. https://doi.org/10.5209/ESMP.55591

Reig, Ramón; Mancinas-Chávez, Rosalba (coords.) (2013). Educación para el mercado. Un análisis crítico de mensajes audiovisuales destinados a menores y jóvenes. Barcelona: Gedisa. ISBN: 9788497847711

Reig, Ramón (2011). Los dueños del periodismo. Claves de la estructura mediática mundial y de España. Barcelona: Gedisa. ISBN: 9788497846189

Reig, Ramón (2010). La telaraña mediática. Cómo conocerla, cómo comprenderla. Sevilla/Zamora: Comunicación Social Ediciones y Publicaciones. ISBN: 9788492860548

Reig, Ramón (1995). El control de la comunicación de masas. Bases estructurales y psicosociales. Madrid: Libertarias/ Prodhufi. ISBN: 8479542535

Reporteros Sin Fronteras (RSF) (2016). Medios de comunicación. Los oligarcas se van de compras. https://rsf.org/sites/default/files/oligarcas_0.pdf

Roiz-Célix, Miguel (2002). La sociedad persuasora: control cultural y comunicación de masas. Barcelona: Paidós. ISBN: 8449313163

Rushkoff, Douglas (2009). Life Inc.: How the world became a corporation and how to take it back. Random House. ISBN: 9781400066896

Scarpellini, Pablo (2019). "Facebook se redime en Wall Street con un cierre de año excepcional que le deja unos beneficios de 22.112 millones". El mundo, 30/1/2019.

https://www.elmundo.es/economia/empresas/2019/01/30/5c521d9afc6c8308038b45cd.html 
Segovia-Alonso, Ana-Isabel (2001). La estructura de los medios de comunicación en Estados Unidos: análisis crítico del proceso de concentración multimedia. E-prints Complutense, UCM. ISBN: 8466922296

https://eprints.ucm.es/4545

Serrano, Pascual (2009). Desinformación: cómo los medios ocultan el mundo. Barcelona: Península. ISBN: 8483079186

Serrano, Pascual (2016). Medios democráticos: una revolución pendiente en la comunicación. Madrid: Akal. ISBN: 84 16842000

Sombras de libertad (2015). Documentos TV. TVE2. 54:17 minutos.

https://www.youtube.com/watch?v=tPFEpGrn2Kc

Thompson, John B. (1998). Los media y la modernidad: una teoría de los medios de comunicación. Barcelona: Paidós. ISBN: 8449305780

Toural-Bran, Carlos; López-García, Xosé (coords.) (2019). Ecosistema de cibermedios en España. Tipologías, iniciativas, tendencias narrativas y desafíos. Salamanca: Comunicación Social Ediciones y Publicaciones. ISBN: 9788417600082

Van-Dijk, Teun A. (1998). Ideology. London: Sage. ISBN: 9780761956549

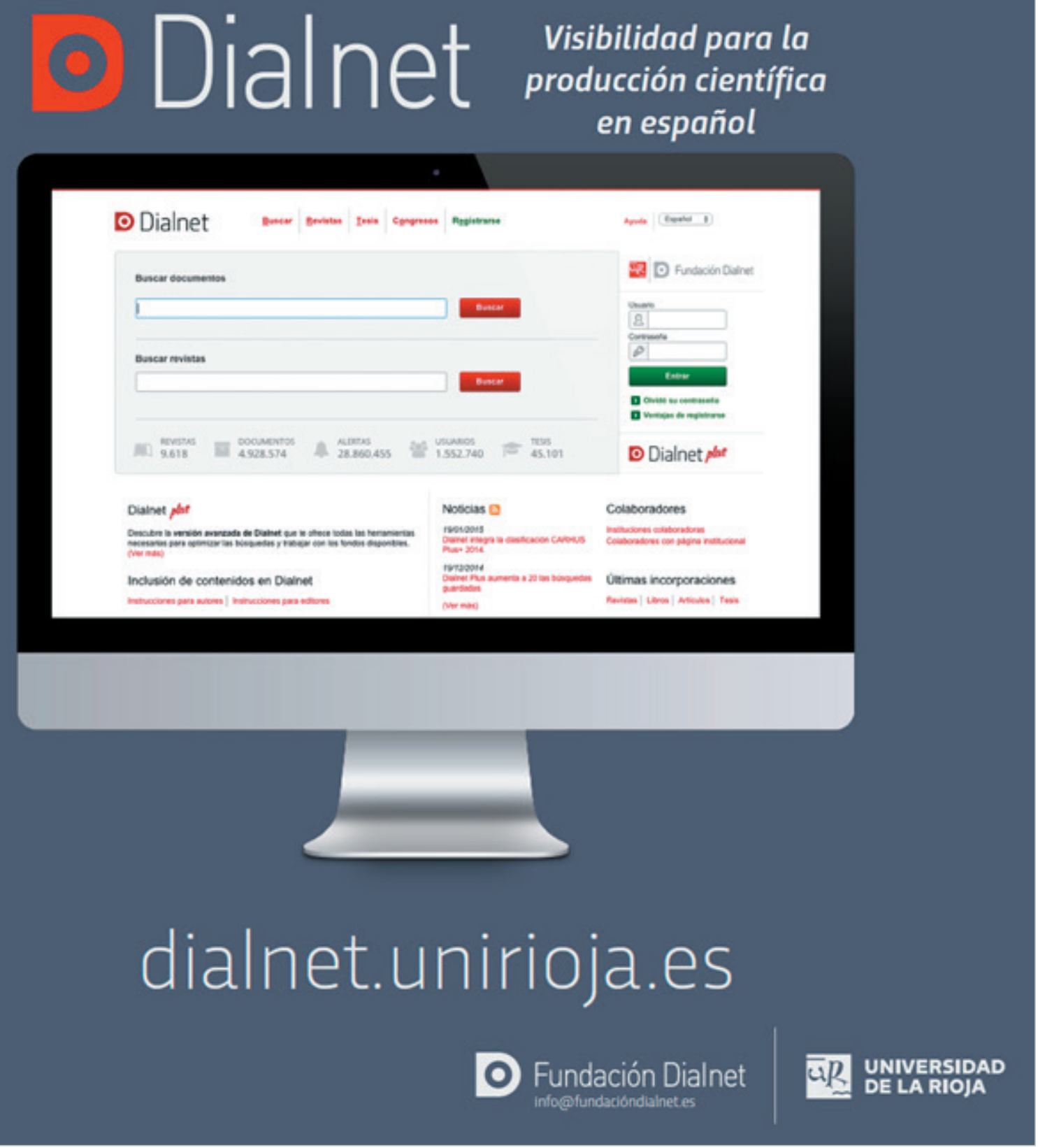

